\title{
DISCOVERY OF DIAMOND DEPOSITS IN THE QUEBRADA GRANDE CATCHMENT, VENEZUELA.
}

\author{
Baxter-Brown, ${ }^{(1)}$ R.; Baker, ${ }^{(2)}$ N.R
}

(1) 101 Walton Heath, 20 Jacobs Lane, Fairways 2196, South Africa; (2) 3 Upper Camden Place, Bath, Avon BA1

$5 H X$, United Kingdom.

A new field of diamondiferous kimberlites, containing at least two types and ages of kimberlite (Nixon et al.,1989) has been discovered during this decade in Venezuela. They are located near the village of La Salvacion in the Guaniamo drainage basin. (See map). These highly prospective diamond source rocks have been intruded into the stable Archaean-Proterozoic Guyana Shield.

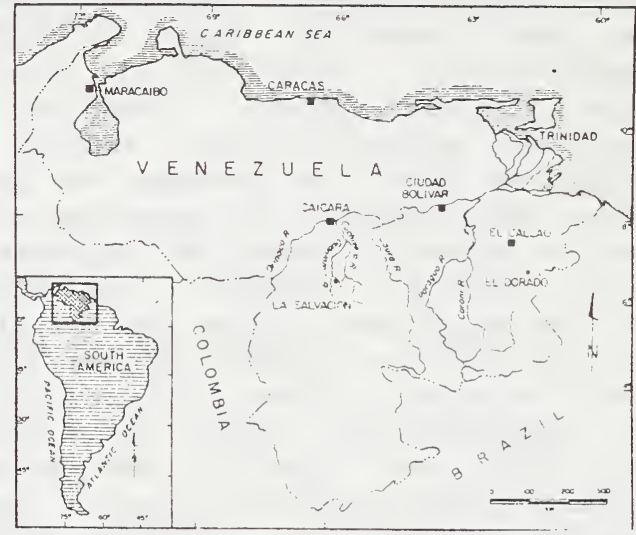

Alluvial diamonds were first discovered in Venezuela in 1887 on the Caroni River, the principal drainage of southeastern Venezuela. Diamonds have since been extracted from placers over a wide area of the Caroni crainage basin by diggers or "mineros". Mining has been on a small scale, using hydraulic jets, or small dredges, with jigs to recover the diamond. Gold is also commonly recovered.

In 1968 a rich alluvial diamond deposit was discovered in the Quebrada Grance, a tributary of the Guaniamo River in the western shield of Venezuela. Between 1969 and 1970 Venezuela's diamond production increased by $158 \%$, reflecting the impact of the Guaniamo discoveries. From 1970 to 1974 this production had expanded to the extent that it was 1.62 times more than the total weight of diamonds produced in Venezuela from 1937 to 1970. (Baptista et al 1978).

While a proximal source rock for Guaniamo's diamonds has been suspected by several experts, no systematic exploration for kimberlite was undertaken until 1982 .

Until recently, all diamonds in northern South America were thought to be multi-cycle, latterly derived from conglomerate bands within the Roraima Formation. For almost a century diamond placers have been worked at localities near the foot of Roraima escarpments and in rivers oraining remnants of this formation. 
The coincioence was convincing and carried with it the implication that the original primary source rocks could be so remote in time as to liave been long eroded below root level, and so remote jn space as actually to be in West Africa. The nearest outlier of Roraima to the Quebrac'a Grande occurs 70 kilometres to the south and lies beyond the Guaniamo drainage. While the Roraima Formation must once have covered much of the western shielc, it could not realistically be invoked as a secondary source for such rich, discrete and individually c'istinct diamond diggings as occur in the restricted area of the oue'orada Grande.

Following a 1982 study of Guaniamo diamoncs it was apparent that local variations in diamond characteristics from virtually adjacent diggings could only be explained by there being a number of local source rocks to which different o'iggings were related. Kimberlite exploration was therefore justified and a six month programme of close-interval stream sediment sampling was started in June 1982. The programme included air photo interpretation supported by RADAM maps, and the construction of a 1:50 000 drainage map of the cuebrada Grande area. A laboratory in San Antonio, Texas, was contracted to treat the Guaniamo samples.

Sample size averaged $80 \mathrm{~kg}$ of $-2 \mathrm{~mm}$ fraction; these were taken from the best stream trap sites available. Initial laboratory concentrates in the +400 micron size range gave no kimberlite indicator minerals and it was not until the -200 micron size fraction was examined that kimberlitic pyropes were recognised. Sample BBV17, taken from the upper Candado drainage - a richly diamondiferous tributary of the Quebrada Grande - yieldec 10 micro-diamonds, 9 kimberlitic garnets and 1 chromite grain. A follow-up sample, JD10, composed of $18 \mathrm{~kg}$ of highly weathereo bedrock clay, yielded 2000 kimberlitic garnets and 4 microdiamonds. This clay proved to be the first primary source rock discovereo in Venezuela (August 1982).

Guaniamo kimberlites are extremely weathered so that olivine and pyroxenes are not liberated to the regolith. Ilmenite appears to be absent anc the chrome spinels are indistinguishable from background species. The most distinctive and common indicator mineral is the high chrome, low calcium variety of pyrope, or Glo variety of Dawson and Stephens (1975). These are highly fractured and reduced to almost colourless -100 micron shards. Analysis of stream gravel samples is thus a painstaking process.

Since 1987 local diggers have learned to recognise weathered kimberlite and its economic significance. Mining has now exposec 15 kimberlite occurrences that extend over a distance of $12 \mathrm{~km}$ by $5 \mathrm{~km}$. The original discovery is pipe-like in appearance, whereas the other exposures consist of horizontal to inclined sheets (up to $15^{\circ}$ ) that are commonly 2 metres thick. The inclined sheets are controlled by the cominant NNW structural trend of the area. Attitude and regional distribution support the view that the original kimberlite cykes have been subjected to post-emplacement folding and/or block-faulting.

Two varieties of diamond bearing mantle rock have been recognised. The older rock has returned a sr whole rock age of $1.9 \mathrm{Ga}+-0.05 \mathrm{Ga}$, whereas $\mathrm{Nd}$ dating indicates $2.0 \mathrm{Ga}+-0.05 \mathrm{Ga}$. Argon dating of the younger rock gives an age of $850 \mathrm{Ma}$. Both varieties have been severely weathereo so that precise bulk chemistry is difficult to determine. However, P.H.Nixon (paper in preparation) is inclined to classify the older rock as a Group 1 
kimberlite. The younger rock tends towards lamproite, with $\mathrm{K}_{2} \mathrm{O}$ around 5\%. Narrow veins of the lamproitic rocl. cut through a horizontal sheet of kimberlite in the 039 Area. This rock is composed mainly of phlogopite with diamond and rare pyrope.

The Guaniamo kimberlites pre-date the deposition of the Roraima Formation $(1.75-1.65 \mathrm{Ga})$, and are intruded into preRoraima Archaean-style Basement. The area has been affecteo by the Cuchivero-Pacaraima thermal event $(1.8-1.9 \mathrm{Ga})$. It is proposed therefore that the folding and faulting of the kimberlites is related to this event and that the $\mathrm{Sr} \&$ No age determinations reflect metamorphic adjustment. Thermal metamorphism may also partly explain the unusual chemistry anc mineralogy of the kimberlite. This proposal implies a greater age for the emplacement of the kimberlite than has been determined. The lamproite occurrence post-dates the Roraima Formation. This fact has important implications for diamonc exploration elsewhere in Venezuela, in particular in those areas where this massive sedimentary cover is widespread and exceeds $3 \mathrm{~km}$ in thickness. Here, lamproites (as well as younger kimberlites) can be expectec to be preserved as large bodies and not erodec to root zones as is the case in Area 039.

The discovery of diamond bearing mantle rocks in Guaniamo is a benchmark event for source rock exploration in Venezuela and the Guyana Shield as a whole. Past myths as to the origin of the placer diamonds have as a result been dispellec and the door is open to a new era of diamond exploration in this prospective region. In addition, recent statements issued by the Venezuelan Government suggest that foreign investment is to be encourager, and exploration for minerals promoted. To maximise its revenue and at the same time limit environmental and ethnographic camage, the Government must convert areas which are at present haphazard diggings, into long term concessions granted to responsible anc accountable mining companies.

\section{REFERENCES}

Baptista, J. \& Svisero, D.P. (1978) Geologia de los depositos diamantiferos de la parte noroccidental de la Guayana Venezolana. Direccion General Sectorial de Minas y Geologia. 23 No 24.

Dawson, J.B. \& Stephens, W.E. (1975) Statistical classification of garnets from kimberlitic and associated xenoliths. Journal of Geology, 83, 589-607.

Nixon, P.H., Davies, G.R., Condliffe, E., Baker, N.R., \& BaxterBrown, R. (1989) Discovery of ancient source rocks of Venezuela diamonis, 28th Geological Congress. Extended Abstracts. Workshop on diamonds, Washington DC. 